\title{
Penerapan Model Pembelajaran Sains Teknologi Masyarakat (STM) untuk Meningkatkan Hasil Belajar Fisika Siswa Kelas VIII SMPN 3 Mataram
}

\author{
Hidayah Lestari' ${ }^{1}$, Syahrial Ayub ${ }^{2}$, Hikmawati ${ }^{2}$ \\ ${ }^{1}$ Alumni Program Studi Pendidikan Fisika \\ ${ }^{2}$ Program Studi Pendidikan Fisika \\ Universitas Mataram \\ Mataram, Indonesia \\ Email: hidayah_lestari@gmail.com
}

\begin{abstract}
This research is a classroom action research (CAR) which aims to improve learning outcomes physics class VIII SMPN 3 Mataram. The sample used in this research is class VIII 3 totaling 30 people, by applying science technology society learning model. Action research consists of four stages: planning, implementation, observation and evaluation, and reflection, while the implementation science technology society learning model is done through the five stages of the preliminary stage, the formation of the concept, application of concepts, strengthening the concept and assessment. This study is successful if students achieve learning outcomes classical completeness $85 \%$ with the value of each student reach $\geq 75$. Based on the evaluation of the obtained value of the average grade in the first cycle of 78.01 with $71.43 \%$ classical completeness. In the second cycle learning outcomes of students has increased, with an average grade of 86.02 and classical completeness amounted to $85.7 \%$. Based on the results of this study concluded that by applying science technology society learning model can improve learning outcomes physics class VIII SMPN 3 Mataram according to the five stages above.
\end{abstract}

Keywords : Science Technology Society, Learning Outcomes.

\section{Pendahuluan}

Ilmu Pengetahuan Alam merupakan sekumpulan ilmu-ilmu serumpun yang terdiri dari biologi, fisika, kimia, geologi, dan astronomi yang berupaya menjelaskan setiap fenomena yang terjadi di alam. Dalam kehidupan sehari-hari sering ditemukan bahwa sedikit sekali siswa yang tertarik pada pelajaran fisika, hal ini disebabkan antara lain karena pengajaran fisika yang kurang menarik sehingga siswa jarang termotivasi untuk mempelajarinya. Selain itu banyak hal lagi persepsi tentang pelajaran sains khususnya fisika yang dianggap sebagai pelajaran yang sangat sulit dan membosankan. Kurangnya rasa ingin tahu siswa serta materi yang begitu padat cenderung menjemukan siswa sehingga menyebabkan rendahnya hasil belajar fisika siswa.

Berdasarkan pengamatan peneliti pada siswa kelas VIII SMPN 3 Mataram diketahui bahwa motivasi, aktivitas, dan hasil belajar siswa masih rendah. Hasil belajar siswa pada pembelajran IPA fisika tidak mencapai rata-rata. Nilai ini masih dibawah Standar Ketuntasan Minimal (SKM) ditetapkan yaitu 75. Berikut ini dicantumkan tentang perolehan nilai ulangan harian siswa SMPN 3 Mataram kelas VIII semester I tahun pelajaran 2014/2015 yang dapat dilihat pada Tabel berikut ini:
Tabel 1. Nilai Rata-Rata Ulangan Harian Mata Pelajaran Fisika Semester I Siswa Kelas VIII SMPN 3 Mataram Tahun Pelajaran 2014/2015

\begin{tabular}{ll}
\hline Kelas & Nilai Rata-Rata \\
VIII 1 & 73,21 \\
VIII 2 & 72,35 \\
VIII 3 & 61,86 \\
VIII 4 & 67,74 \\
VIII 5 & 72,08 \\
VIII 6 & 63,23 \\
VIII 7 & 71,03 \\
VIII 8 & 62,67 \\
\hline
\end{tabular}

Berdasarkan hasil observasi yang saya lakukan di SMPN 3 Mataram pada kelas VIII 3 beberapa siswa cenderung tidak memperhatikan guru ketika menjelaskan. Hal ini mengakibatkan proses pembelajaran menjadi tidak maksimal, sehingga akan berdampak pada berkurangnya pemahaman siswa mengenai konsep yang dijelaskan. Selain itu, siswa berpendapat bahwa pelajaran fisika adalah pelajaran yang sulit dan membosankan, karena terlalu banyak konsep dan rumus-rumus yang sulit mereka pahami, serta hitung-hitungan yang mereka anggap rumit. 
Seharusnya pembelajaran sains adalah pembelajaran dimana siswa tidak hanya dituntut untuk lebih banyak mempelajari konsep-konsep dan prinsipprinsip sains secara verbalitas, hafalan, pengenalan rumus-rumus, dan pengenalan istilah-istilah melalui serangkaian latihan secara verbal, namun hendaknya dalam pembelajaran sains, guru lebih banyak memberikan pengalaman kepada siswa untuk lebih mengerti dan membimbing siswa agar dapat menggunakan pengetahuan tersebut dalam kehidupan sehari-hari.

Dalam kurikulum pendidikan nasional tahun 2006 (KTSP), pendidikan sains merupakan kelompok mata pelajaran ilmu pengetahuan dan teknologi. Pemberian mata pelajaran sains bagi anak dimaksudkan untuk memperoleh kompetensi ilmu pengetahuan dan teknologi serta membudayakan berfikir ilmiah secara kritis, kreatif dan mandiri. Prinsip pengembangan kurikulum didasarkan bahwa peserta didik memiliki posisi sentral untuk mengembangkan kompetensinya agar menjadi manusia yang beriman dan bertakwa, berakhlak mulia, sehat, berilmu, cakap, kreatif, mandiri dan menjadi warga negara yang demokratis serta bertanggung jawab. Untuk mendukung pencapain tujuan tersebut pengembangan kompetensi peseta didik harus disesuaikan dengan potensi, perkembangan, kebutuhan, dan kepentingan peserta didik serta tuntutan lingkungan.

Berdasarkan dengan hal tersebut perlu diupayakan model pembelajaran yang mendorong munculnya belajar bermakna pada peserta didik, yakni bagaimana mereka mampu melibatkan diri secara fisik, mental dan intlektual dalam aktivitas belajarnya. Salah satu model pembelajaran yang diduga kuat dapat memenuhi harapan tersebut adalah model pembelajaran Sains Teknologi Masyarakat (STM).

Model pembelajaran sains teknologi masyarakat ialah model pembelajaran yang mengaitkan antara sains dan teknologi serta manfaatnya bagi masyarakat [6]. Skema tahapan dari model pembelajaran Sains Teknologi Masyarakat (STM) dapat dilihat pada Gambar 1 sebagai berikut:

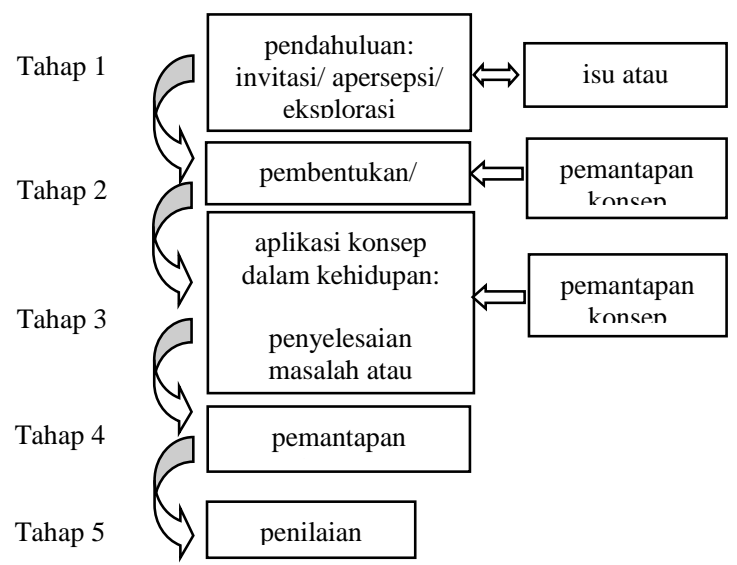

Gambar 1. Model Pembelajaran Sains Teknologi Masyarakat
Kekhasan dari model ini adalah bahwa pada pendahuluan dikemukakan isu-isu atau masalah yang ada dimasyarakat yang dapat digali dari siswa, tetapi apabila guru tidak berhasil memperoleh tanggapan dari siswa dapat saja dikemukakan oleh guru sendiri. Tahap ini dapat disebut dengan inisiasi atau mengawali, memulai, dan dapat pula disebut dengan invitasi yaitu undangan agar siswa memusatkan perhatian pada pembelajaran. Apersepsi dalam kehidupan juga dapat dilakukan, yaitu mengaitkan peristiwa yang telah diketahui siswa dengan materi yang akan dibahas, sehingga tampak adanya kesinambungan pengetahuan, karena diawali dengan hal-hal yang telah diketahui siswa yang sebelumnya yang ditekankan pada keadaan yang ditemui dalam keadaan sehari-hari. Dengan kata lain, model pembelajaran STM merupakan suatu model pembelajaran yang mengaitkan antara sains dan teknologi serta pemanfaatanya bagi masyarakat. Tujuan dari model pembelajaran ini ialah untuk membentuk individu yang memiliki literasi sains dan teknologi serta memiliki kepedulian terhadap masalah masyarakat dan lingkungannya. Dengan model pembelajaran STM ini siswa diharapkan lebih aktif, termotivasi, dan hasil belajar siswa dapat meningkat.

Hasil belajar dapat dijelaskan dengan memahami dua kata yang membentuknya, yaitu "hasil" dan "belajar". Pengertian hasil (product) menunjukkan pada suatu perolehan akibat dilakukannya suatu aktivitas atau proses yang mengakibatkan berubahnya input secara fungsional. Hasil produksi adalah perolehan yang didapatkan karena adanya kegiatan mengubah bahan (raw materials) menjadi barang jadi (finished goods) [7]. Hasil belajar adalah pola-pola perbuatan, nilai-nilai, pengertian-pengertian, sikapsikap, apresiasi dan keterampilan [10].

Hasil belajar yang dicapai siswa dipengaruhi oleh dua faktor utama yakni faktor dari dalam diri siswa itu dan faktor yang datang dari luar diri siswa atau faktor lingkungan. Faktor yang datang dari diri siswa terutama kemampuan yang dimilikinya. Faktor kemampuan siswa besar sekali pengaruhnya terhadap hasil belajar yang dicapai. Seperti yang dikemukakan oleh Clark bahwa hasil belajar siswa di sekolah 70\% dipengaruhi oleh kemampuan siswa dan 30\% dipengaruhi oleh lingkungan. Disamping faktor kemampuan yang dimiliki siswa, juga ada faktor lain, seperti motivasi belajar, minat dan perhatian, sikap dan kebiasaan belajar, ketekunan, sosial ekonomi, faktor fisik dan psikis [9].

Beberapa penelitian telah menyatakan keberhasilan penerapan model pembelajaran Sains Teknologi Masyarakat (STM) dalam meningkatkan hasil belajar. Seperti hasil penelitian [6] menyatakan bahwa penerapan model pembelajaran Sains Teknologi Masyarakat (STM) dapat meningkatkan aktivitas dan hasil belajar siswa. Sama halnya dengan hasil penelitian yang dilakukan oleh [8] yang menyatakan 
bahwa terdapat perbedaan hasil belajar siswa yang menggunakan pendekatan STM lebih tinggi daripada menggunakan pendekatan konvensional.

Model pembelajaran STM memiliki tahapantahapan yang dapat mendukung meningkatnya aktivitas dan hasil belajar siswa. Hal ini sesuai dengan penelitian yang dilakukan oleh [1] yang menyatakan bahwa model STM dapat dikelompokkan menjadi lima tahap yaitu : 1) Pendahuluan: Eksplorasi terhadap siswa, 2) Pembentukan konsep, 3) Aplikasi konsep dalam kehidupan, 4) Pemantapan konsep, dan 5) Penilaian. Berdasarkan tahap-tahap tersebut dapat dikemukakan bahwa model STM menghubungkan antara materi pembelajaran dengan teknologi yang ditemukan siswa dalam kehidupan sehari-hari. Model STM ini cocok untuk digunakan dalam pengembangan LKS. Dengan langkah-langkah yang diterapkan dalam LKS berbasis Sains Teknologi Masyarakat dapat mendidik siswa untuk berpikir kritis dan bersikap ilmiah. Dengan cara ini konsep-konsep yang ada dalam pembelajaran fisika akan lebih mudah dipahami. Pembelajaran dengan menggunakan LKS berbasis STM ini dapat meningkatkan hasil kompetensi siswa dari setiap ranah yaitu ranah kognitif, ranah afektif, dan ranah psikomotor. Penelitian sebelumnya [5] juga telah membuktikan bahwa minat belajar dan prestasi belajar meningkat setelah diterapkan model pembelajaran Sains Teknologi Masyarakat.

Keaktifan siswa dalam proses pembelajaran dapat membantu siswa untuk memecahkan masalah fisika, contohnya dengan cara mengajukan pertanyaan dan berani mengemukakan pendapatnya. Hal ini didukung oleh penelitian yang dilakukan [3] yang menyatakan bahwa aktivitas siswa dalam pembelajaran dapat melatih siswa mengkaji sendiri pola pikirnya untuk menciptakan pernyataan (ungkapan) pengetahuan dari bahasa sendiri sesuai dengan materi yang diajarkan. Selain itu, siswa pun akan lebih berani menyampaikan pendapat dan pertanyaan dari masalah yang dihadapinya dalam fisika sesuai dengan apa yang diketahuinya.

\section{METODE PENELITIAN}

Penelitian ini dilaksanakan di SMPN 3 Mataram. Jenis penelitian ini adalah Penelitian Tindakan kelas (PTK) yaitu PTK didefinisikan sebagai penelitian yang dilakukan oleh guru dikelasnya sendiri melalui refleksi diri dengan tujuan untuk memperbaiki kinerjanya sehingga hasil belajar siswa meningkat [2]. Penelitian ini dilaksanakan pada tanggal 21 Mei 2015 sampai tanggal 4 Juni 2015. Subyek penelitian ini adalah siswa kelas VIII 3 SMPN 3 Mataram, sedangkan obyek penelitian ini adalah peningkatan hasil belajar fisika siswa. Dalam penelitian ini faktor yang diteliti adalah faktor siswa yaitu dengan melihat peningkatan hasil belajar siswa dan faktor guru yaitu dengan melihat kegiatan guru selama pembelajaran di kelas apakah sudah sesuai dengan skenario pembelajaran yang dibuat.

Penelitian ini dilaksanakan dalam dua siklus. Setiap siklus berlangsung selama beberapa kali pertemuan tergantung pada indikator materi setiap sub materi pokok dan perubahan yang ingin dicapai. Akan tetapi, jika pada pelaksanaan siklus I sudah memenuhi kriteria ketuntasan, maka penelitian akan dihentikan dan pelaksanaan siklus selanjutnya tidak akan dilaksanakan.

Penelitian dikatakan berhasil apabila hasil belajar siswa mencapai ketuntasan klasikal $\geq 85 \%$ dengan kriteria ketuntasan minimal per siswa sebesar $\geq 75$. Aktivitas belajar guru dianalisis secara deskriptif berdasarkan deskriptor yang muncul pada lembar observasi aktivitas, sedangakan hasil belajar siswa ranah kognitif dianalisis menggunakan tes pilihan ganda yang diberikan pada akhir tiap siklus.

\section{HASIL DAN PEMBAHASAN}

Dalam penelitian ini yang dinilai tidak hanya hasil belajar siswa, melainkan aktivitas peneliti sebagai guru di kelas juga dinilai dan diamati. Adapun perbandingan hasil belajar siswa pada siklus I dan II adalah sebagai berkut:

Tabel 2. Perbandingan Hasil Belajar Siswa pada Siklus I dan II

\begin{tabular}{llllll}
\hline Siklus & $\begin{array}{l}\text { Jumlah } \\
\text { siswa }\end{array}$ & $\begin{array}{l}\text { Rata- } \\
\text { rata } \\
\text { kelas }\end{array}$ & $\begin{array}{l}\text { Siswa } \\
\text { tuntas }\end{array}$ & $\begin{array}{l}\text { Siswa } \\
\text { tidak } \\
\text { tuntas }\end{array}$ & $\begin{array}{l}\text { Ketuntasan } \\
\text { klasikal }\end{array}$ \\
I & 28 & 78,01 & 20 & 8 & $71,43 \%$ \\
II & 28 & 86,02 & 24 & 4 & $85,7 \%$ \\
\hline
\end{tabular}

Untuk lebih jelasnya perbandingan siswa yang tuntas dengan tidak tuntas, dapat dilihap pada diagram berikut.

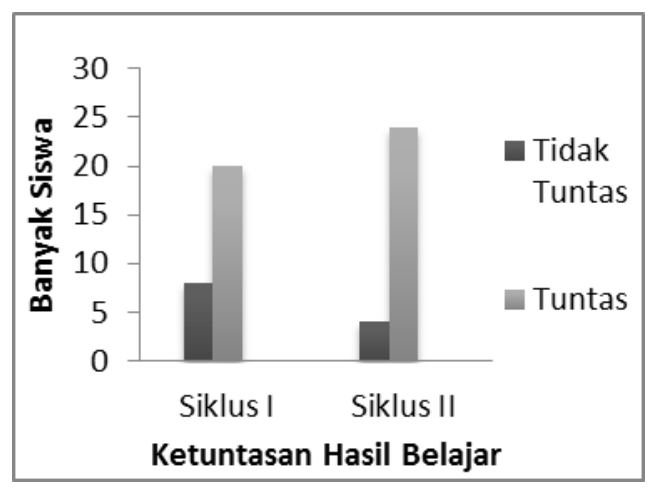

Gambar 2. Diagram Perbandingan Siswa yang Tuntas dengan Tidak Tuntas pada Siklus I dan II

Tabel perbandingan hasil observasi aktivitas guru pada siklus I dan II adalah sebagai berkut. 
Tabel 3. Perbandingan Hasil Observasi Aktivitas Guru pada Siklus I dan II

\begin{tabular}{lll}
\hline Siklus & Skor Aktivitas Guru & Kriteria Aktivitas \\
I & 8,33 & Cukup Baik \\
II & 11,99 & Sangat Baik \\
\hline
\end{tabular}

Untuk lebih jelasnya perbandingan aktivitas guru di kelas setiap siklusnya dapat dilihat pada diagram berikut.

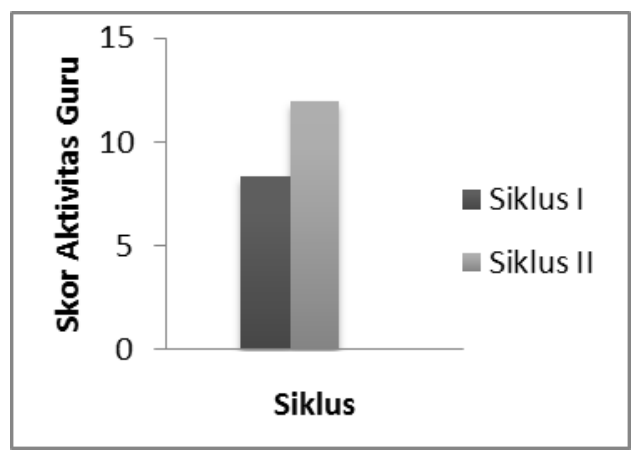

Gambar 3. Diagram Perbandingan Hasil Observasi Aktivitas Guru pada Siklus I dan II

Berdasarkan hasil penelitian, pada siklus I diperoleh nilai rata-rata siswa sebesar 78,01 dengan ketuntasan klasikal 71,43\%. Hasil observasi aktivitas guru yang diamati guru mata pelajaran IPA pada siklus I diperoleh aktivitas guru berkriteria cukup baik. Rendahnya hasil belajar siswa disebabkan karena masih ada siswa yang kurang memperhatikan penjelasan guru saat proses pembelajaran, dan belum terbiasa bekerja sama dengan teman kelompoknya sehingga masih ada siswa yang sifatnya individual dalam mengerjakan LKS. Siswa juga belum percaya diri untuk mempresentasikan hasil diskusi kelompok mereka dihadapan teman-temannya. Selain itu, kurangnya waktu saat proses pembelajaran sehingga guru masih belum maksimal dalam melakukan tahaptahap pembelajaran yang terdapat dalam RPP.

Hasil belajar siswa pada siklus 1 belum mencapai indikator keberhasilan yakni siswa yang memperoleh nilai $\geq 75$ masih berada di bawah $85 \%$, oleh karena itu penelitian dilanjutkan ke siklus 2. Setelah dilakukan perbaikan-perbaikan pada siklus 2 , diperoleh data hasil belajar siswa mengalami perbaikan yakni nilai rata-rata siswa sebesar 86,02 dengan ketuntasan klasikal $85,7 \%$. Hasil observasi aktivitas guru yang diamati guru mata pelajaran IPA pada siklus 2 diperoleh aktivitas guru berkriteria sangat baik. Hasil tersebut terlihat bahwa hasil belajar siswa sudah mencapai indikator keberhasilan karena siswa yang memperoleh nilai $\geq 75$ berada di atas $85 \%$. Karena hasil belajar siswa sudah mencapai indikator keberhasilan, maka penelitian ini hanya sampai pada siklus 2. Adanya peningkatan hasil belajar siswa pada siklus 2 ini disebabkan karena siswa terlibat aktif selama kegiatan pembelajaran. Selain itu, guru juga telah memperbaiki kekurangan-kekurangan yang ada pada proses pembelajaran pada siklus 1 .

Berdasarkan hasil penelitian dan pembahasan di atas, diperoleh data hasil belajar siswa yang mengalami peningkatan dari siklus 1 ke siklus 2 dan mencapai indikator keberhasilan pada siklus 2 . Dengan demikian, penerapan model pembelajaran sains teknologi masyarakat pada materi alat-alat optik dapat meningkatkan hasil belajar fisika siswa. Hal ini sesuai dengan hasil penelitian sebelumnya yang meneliti aktivitas dan hasil belajar siswa dengan menerapkan model pembelajaran sains teknologi masyarakat. Penelitian sebelumnya ini menyatakan bahwa pembelajaran dengan menerapkan model pembelajaran sains teknologi masyarakat dapat meningkatkan aktivitas dan hasil belajar siswa [4].

Meskipun terdapat perbedaan subyek dan obyek penelitian, namun hasil yang diperoleh memiliki kesamaan yakni model pembelajaran sains teknologi masyarakat dapat meningkatkan kemampuan yang dimiliki oleh siswa. Model pembelajaran sains teknologi masyarakat dapat digunakan sebagai alternatif pembelajaran untuk meningkatkan hasil belajar siswa pada materi pokok alat-alat optik.

\section{PENUTUP}

Berdasarkan hasil penelitian dan pembahasan, maka dapat disimpulkan model pembelajaran sains teknologi masyarakat dapat meningkatkan hasil belajar fisika siswa kelas VIII 3 SMPN 3 Mataram pada materi pokok alat-alat optik. Nilai rata-rata hasil belajar siswa pada siklus 1 sebesar 78,01 dengan aktivitas guru berkategori cukup baik. Pada siklus 2 nilai rata-rata hasil belajar siswa sebesar 86,02 dengan aktivitas guru berkategori sangat baik. Kentutasan klasikal hasil belajar siswa pada siklus 1 sebesar $71,43 \%$, pada siklus 2 mengalami peningkatan sebesar $85,7 \%$.

Model pembelajaran sains teknologi masyarakat dapat digunakan peneliti lain pada materi pokok lainnya. Saat proses pembelajaran dengan menerapkan model pembelajaran sains teknlogi masyarakat berlangsung, diharapkan siswa lebih fokus memperhatikan guru agar hasil yang diperoleh lebih optimal.

\section{REFERENSI}

[1] Asmirani, U. 2013. Pengaruh LKS Berbasis Sains Teknologi Masyarakat Terhadap Kompetensi Siswa dalam Pembelajaran IPA Fisika Di Kelas VIII SMPN 1 Kubung Kabupaten Solok. Pillar of Physics Education Vol. 1 Halaman 85-90: Diterbitkan.

[2] Aqib, Z., Diniati, E., Jaiyaroh, S. dan Khotimah, K. 2011. Penelitian Tindakan Kelas untuk Guru SMP, SMA, SMK. Yrama Widya: Bandung.

[3] Dewi, E. B. C. 2014. Pengaruh Aktivitas pada Pembelajaran Sains Teknologi Masyarakat 
Terhadap Hasil Belajar Fisika Siswa. Jurnal FKIP Universitas Lampung: Tidak Diterbitkan.

[4] Febrianti, V. F. 2013. Meningkatkan Aktivitas dan Hasil Belajar Fisika Melalui Model Pembelajaran Sains Teknologi Masyarakat pada Siswa Kelas XA SMA Negeri 2 Dolo. Jurnal Pendidikan Fisika Tadulako (JPFT) Vol. 1 Halaman 38-41: Diterbitkan.

[5] Gunarto, W. 2014. Upaya Meningkatkan Minat Belajar dan Prestasi Belajar Siswa pada Materi Pembelajaran Alat-Alat Optik Melalui Pendekatan Saians Teknologi Masyarakat Di Kelas VIII SMPN 3 Belitang Madang Raya. Jurnal Inovasi dan Pembelajaran Fisika Vol. 1 Halaman 28-32: Diterbitkan.

[6] Poedjiadi, A. 2010. Sains Teknologi Masyarakat Model Pembelajaran Kontekstual Bermuatan Nilai. Remaja Rosdakarya: Bandung.

[7] Purwanto. 2013. Evaluasi Hasil Belajar. Pustaka Pelajar: Yogyakarta.

[8] Siagian, H. 2014. Perbedaan Hasil Belajar Siswa yang Diajarkan Dengan Pendekatan Sains Teknologi Masyarakat dan Pendekatan Konvensional pada Materi Pokok Kalor dan Perpindahan. Jurnal Penelitian Bidang Pendidikan Vol. 20 Halaman 22-29: Diterbitkan.

[9] Sudjana, N. 2014. Dasar-dasar Proses Belajar Mengajar. Sinar Baru Algensindo: Bandung.

[10] Suprijono, A. 2014. Cooperative Learninng Teori dan Aplikasi PAIKEM. Pustaka Pelajar: Yogyakarta.

\section{Biografi Penulis}

Hidayah Lestari, lahir di Alas, 14 Desember 1991. Penulis merupakan alumni S1 Pendidikan Fisika, Jurusan Pendidikan MIPA, FKIP, Universitas Mataram.

Syahrial Ayub, lahir di Dumai, 5 Juni 1970. Riwayat Pendidikan: S1 Pendidikan Fisika di FPMIPA IKIP Padang, S2 Fisika di UGM Yogyakarta. Riwayat Pekerjaan: Dosen pada Program Studi S1 Pendidikan Fisika FKIP Unram sejak tahun 1997 sampai sekarang.

Hikmawati, lahir di Montong Bulok, Lombok Tengah, 31 Desember 1981. Riwayat Pendidikan: S1 Pendidikan Fisika di FKIP Unram, S2 Pendidikan Sains di UNESA Surabaya. Riwayat Pekerjaan: Dosen pada Program Studi S1 Pendidikan Fisika FKIP Unram sejak tahun 2005 sampai sekarang. 